\title{
PENGARUH KEADILAN, KECURANGAN TEKNOLOGI, DISKIRIMINASI DAN NILAI SOSIAL TERHADAP PERSEPSI WAJIB PAJAK MENGENAI ETIKA PENGGELAPAN PAJAK (TAX EVASION)
}

\author{
Mulur Veronika*1, Muhammad Saleh ${ }^{* 2}$ \\ ${ }^{1,2}$ Program Studi Akuntansi Fakultas Ekonomi dan Bisnis Universitas Syiah Kuala \\ e-mail: siddiq.veronika@yahoo.com ${ }^{* 1}$, saleh_feusk@ unsyiah.ac.id ${ }^{* 2}$
}

\begin{abstract}
Taxes are the most important element in sustaining the budget in the form of state revenues. Running and realizing a national development plan, the government needs substantial funds to make it happen. But in reality there are many taxpayers who violate their tax obligations by carrying out tax evasion. This study aims to analyze the influence of justice, technology fraud, discrimination and social values on the perceptions of taxpayers regarding the ethics of tax evasion. The population of this study is taxpayers registered at KPP Pratama Banda Aceh. The sample in this study was determined based on the convenience sampling method, the data was collected by dividing 150 questionnaires. The method of research analysis used is multiple linear regression. The data uses the SPSS version 22 program. Based on the results and conclusions, the research shows that fairness, technology fraud, discrimination and social values have a positive and significant effect on the perception of taxpayers regarding the ethics of tax evasion. Overall, all four variables simultaneously influence tax evasion. Future studies are expected to be able to use other variables beyond this research model to enrich science, especially in the field of tax.
\end{abstract}

Keywords: Justice, technology fraud, discrimination and social values, Taxpayer Ethics Perception, Tax Evasion

\section{Pendahuluan}

Pajak merupakan unsur yang paling penting dalam menopang anggaran terdahap penerimaan negara. Menjalankan dan merealisasikan rencana pembangunan nasional, pemerintah memerlukan dana yang cukup besar untuk mewujudkannya. Direktoral Jenderal (Ditjen) Pajak, instansi pemerintah di bawah Departemen Keuangan sebagai pengelola sistem perpajakan di indonesia, terus melakukan tugas pokoknya dengan meningkatkan penerimaan pajak dalam pelaksanaan sistem perpajakan menjadi lebih modern. Hampir semua pemasukan negara yang berasal dari pajak digunakan untuk keperluan rakyat dalam mensejahterakan dan memakmurkan(Waluyo, (2010:1)).

Pajak yaitu iuran yang wajib dibayarkan kepada negara menurut peraturan undang-undang yang berlaku dapat dipaksa dan tanpa adanya imbal jasa secara langsung yang di pakai untuk membiayai pengeluaran umum negara. Masyarakat menganggap bahwa pajak adalah beban karena mengurangi penghasilan mereka, terlebih lagi tidak mendapat imbalan langsung ketika membayar pajak. Belum mencapai target, pemerintah terus berupaya khususnya kementrian keuangan (Kemenkeu) dalam mengejar penerimaan negara di APBN 2016 di nilai perlu mendapatkan apresiasi. Salah satunya, penerimaan pajak yang mencapai 81,54 persen dari target. Anggota Komisi XI DPR Mukhamad Misbakhun mengatakan, penerimaan pajak secara keseluruhan per 31 Desember 2016 mencapai Rp. 1.105 triliun, atau sebesar 81.54 persen dari target penerimaan pajak di APBN perubahan 2016 yang sebesar Rp. 1.355 triliun. Penerimaan total itu tumbuh sekitar 4.13 persen di bandingkan dengan 2015. Penerimaan negara dari sektor pajak hingga bulan november 2017 mencapai 78 persen dari total target keseluruhan. Adapun target penerimaan pajak 2017 yang di tetapkan pemerintah sebesar Rp. 1.283,6 triliun.

Setiap tahun jumlah pemasukan dari pajak yang disetorkan selalu meningkat tetapi di sisi lain masyarakat belum merasakan pemerataan dari pajak yang di setor secara adil (Prasetyo, (2010:26)). Suminarsasi (2012:2) mengemukakan bahwa sistem perpajakan di indonesia yang belum optimal, serta pemahaman wajib pajak yang masih rendah terhadap peraturan perpajakan yang berlaku merupakan salah satu faktor yang dapat memicu Wajib Pajak 
melakukan tax evasion (penggelapan pajak). Munculnya oknum makelar pajak seperti Gayus, Dhana Widyatmika dan banyak petugas lainnya membuat keyakinan wajib pajak atas kinerja pelayanan pajak berkurang sehingga wajib pajak tidak mau membayar pajak karena takut uangnya di gelapkan, adanya biaya yang dipungut bukan untuk pembangunan negara (Nugroho, 2012). Kejadian seperti itu, maka aparat pajak dituntu untuk memberikan pelayanan yang ramah, adil, dan tegas kepada wajib pajak serta dapat membuat kesadaran wajib pajak tentang tanggung jawab membayar pajak (Fikriningrum, 2012:2)).

Penggelapan pajak (tax evasion) dapat di lakukan oleh orang pribadi salah satu faktornya adalah kurang memahami ketentuan perpajakan, UndangUndang perpajakan dan pemanfaatan akan adanya celah dalam Undang-Undang Perpajakan (loopholes), sehingga dapat di salah gunakan untuk melakukan penggelapan pajak, seperti tidak jujur dalam memberikan data keuangan maupun menyembunyikan data keuangan (Siahaan, 2010). Ada beberapa kasus penggelapan pajak yang terjadi di indonesia salah satunya kasus yang sering di lakukan petugas pajak, seperti yang di lakukan oleh Gayus Tambunan dan Dhana Widyatmika, mereka tidak hanya melakukan penggelapan pajak saja tetapi suap pajak. Penggelapan pajak juga dilakukan oleh Alexander Patra pimpinan Sony Elektonik, dengan sangkaan menyampaikan surat pemberitahuan (SPT) yang isinya tidak benar, melaporkan omset yang tidak sesuai dengan keadaan sebenarnya, sehingga negara mengalami kerugian sebesar Rp. 5M.

\section{Kajian Pustaka \\ Pengertian Pajak}

Definisi pajak menurut Undang-Undang Nomor 16 tahun 2009, yaitu kontribusi wajib kepada negara yang terutang oleh orang pribadi atau badan yang bersifat memaksa berdasarkan Undang-Undang, dengan tidak mendapatkan imbalan secara langsung dan digunakan untuk keperluan negara bagi sebesarbesarnya kemakmuran rakyat. Rochmat Soemitro, pajak adalah iuran rakyat kepada kas negara berdasarkan undang-undang (yang dapat dipaksakan) dengan tiada mendapat jasa timbal (kontraprestasi) yang langsung dapat ditunjukkan dan yang digunakan untuk membayar pengeluaran umum (Mardiasmo,2016:3).

Pajak adalah iuran dari rakyat kepada negara berarti yang berhak memungut pajak hanyalah negara. Iuran tersebut berupa uang (bukan barang) sehingga dapat dipaksakan dan tanpa adanya imbal jasa (kontraprestasi) secara langsung yang digunakan untuk membiayai pengeluaran umum negara. Berdasarkan undang-undang pajak dipungut berdasarkan atau dengan kekuatan undang-undang serta aturan pelaksanaanya.

\section{Pengertian Wajib Pajak (WP)}

Suryani dan Tarmudji (2012:30), menyatakan bahwa wajib pajak adalah orang pribadi atau badan yang menurut ketentuan peraturan perundangundangan perpajakan ditentukan untuk melakukan kewajiban perpajakan, termasuk pemungut pajak dan pemotong pajak tertentu. Wajib Pajak ini terdiri dari dua jenis yaitu Wajib Pajak Orang Pribadi dan Wajib Pajak badan yang memenuhi definisi sebagai subjek pajak dan menerima atau memperoleh penghasilan yang merupakan objek pajak

\section{Persepsi}

Menurut A.Lubis (2010:45), persepsi adalah bagaimana orang-orang melihat atau menginterpretasikan peristiwa, objek, serta manusia. Persepsi juga merupakan pengalaman tentang objek atau hubungan-hubungan yang diperoleh dengan menyimpulkan informasi dan menafsirkan pesan. Persepsi merupakan pandangan pikiran seseorang yang muncul dari kegiatan mengorganisasikan dalam pikirannya, menafsirkannya, mengalami, dan mengelola pertanda atas segala sesuatu yang terjadi di lingkungannya (Prasetyo, (2010:22)).

\section{Etika}

Etika berasal dari kata yunani ethos (bentuk tunggal) yang berarti: tempat tinggal, padang rumput, kandang, kebiasaan, adat, watak, perasaan, sikap, cara berpikir (Agoes \& Ardana, 2014:34). Etika adalah kebiasaan hidup yang baik timbul dari diri seseorang maupun pada suatu masyarakat atau berkelompok dan menghindari tindakan yang buruk (Silaen, (2015:34)). Etika mencerminkan perilaku seseorang yang baik dan tidak baik dalam kehidupannya. Istilah etika sangat berhubungan dengan tata krama, sopan santun, 
penalaran moral, norma susila, dan lain-lain yang mana hal-hal ini berhubungan juga dengan normanorma yang ada di dalam masyarakat (Abrahams \& Kristanto, 2016:34).

\section{Penggelapan Pajak (Tax Evasion)}

Menurut Mardiasmo (2016:427)), penggelapan pajak merupakan usaha meringankan beban pajak dengan cara melanggar undang-undang. Cara yang digunakan oleh wajib pajak untuk melakukan penggelapan pajak akan merugikan Negara dan tentunya akan dikenakan sanksi administrasi dan pidana bagi pihak-pihak yang melakukan cara tersebut. Penggelapan pajak juga dapat dipandang sebagai tindakan yang paling dibenarkan apabila dana pajak yang terkumpul terbuang sia-sia, sistem pajak dilihat tidak adil dan pemerintah mendiskriminasikan beberapa segmen penduduk (Nickerson et al., (2009)).

\section{Keadilan Pajak}

Keadilan adalah sesuatu yang diberikan kepada siapa saja sesuai dengan haknya, karena keadilan berkaitan dengan hak dan kewajiban seseorang (Mukharoroh, (2014:40)). Keadilan pajak adalah keadilan dalam menerapkan sistem perpajakan yang ada (Kurniawati \& Toly, 2014). Misalnya, setiap warga Negara harus ikut serta mengambil bagian dalam pembiayaan pemerintah dan bentuk partisipasi tersebut harus proposional sesuai dengan kemampuan masing-masing, yaitu dengan cara membandingkan penghasilan yang diperolehnya dengan perlindungan yang dinikmati dari Negaranya.

\section{Kecurangan Teknologi}

Kecurangan teknologi pajak dapat diketahui dengan melakukan pemeriksaan sistem perpajakan yang ada dikomputer. Kecurangan komputer merupakan segala bentuk penipuan yang membutuhkan pengetahuan dalam teknologi komputer untuk melakukan tindakan awal, penyelidikan, atau pun dalam pelaksanaan langsung penipuan tersebut. Kecurangan teknologi yang terjadi di perpajakan ini tidak hanya dilakukan oleh aparat pelayanan pajak saja. Bisa dilakukan oleh wajib pajak itu sendiri dengan memanfaatkan informasi teknologi yang ada.

\section{Diskriminasi}

Menurut wikipedia (2016) diskriminasi merujuk kepada pelayanan yang tidak adil terhadap individu tertentu, dimana layanan ini dibuat berdasarkan karateristik yang diwakili oleh individu tersebut. Diskriminasi merupakan kejadian yang banyak dijumpai dalam masyarakat luas, ini disebabkan karena kecenderungan manusia untuk membedabedakan yang lain. Diskriminasi menyebabkan Wajib Pajak merasa diperlakukan secara tidak adil akibat dari penerapan sistem yang memihak atau peraturan perpajakan yang diterapkan secara tidak baik (Hasibuan, (2014:49)).

\section{Nilai Sosial}

Nilai adalah segala sesuatu yang dihargai masyarakat karena memiliki daya guna fungsional untuk perkembangan kehidupan manusia. Nilai Salah satu alasan yang dapat mencegah masyarakat untuk berkoordinasi seputar korupsi yang rendah dan penghindaran pajak yang rendah adalah kurangnya kepercayaan, yang tampaknya ada di banyak masyarakat. Konteks di mana beberapa bentuk "legitimasi" norma-norma korup berlaku, nampaknya penguatan moral masyarakat ini justru bisa mengarah pada penegakan kebijakan pencegahan standar yang lebih baik (Kimball Young (2003:14)).

\section{Kerangka Pemikiran}

\section{Keterkaitan Antar Variabel 2.2.2 Keadilan Dengan Etika Penggelapan Pajak}

McGee, et al (2008) penggelapan pajak dipandang perilaku yang tidak beretika. Keadilan memiliki pengaruh yang penting terhadap etika penggelapan pajak, adanya pemikiran tentang pentingnya keadilan bagi seseorang dalam membayar pajak juga akan mempengaruhi sikap mereka dalam melakukan pembayaran pajak. Semakin rendahnya keadilan terhadap pajak maka tingkat kepatuhan akan semakin menurun hal ini cenderung untuk melakukan penggelapan pajak semakin meningkat. Maka hipotesisnya yaitu:

$\mathrm{H}_{1}$ : Keadilan berpengaruh positif terhadap etika penggelapan pajak 


\section{Kecurangan Teknologi Dengan Etika Penggelapan Pajak}

Ayu (2009:7)) semakin ketat pemeriksaan pajak maka semakin sedikit kemungkinan kecendrungan wajib pajak melakukan kecurangan. Kecurangan bisa dilakukan oleh wajib pajak itu sendiri maupun petugas pajak, Semakin tinggi pemeriksaan maka mereka akan cenderung patuh terhadap peraturan pajak sehingga mereka tidak melakukan tindakan penggelapan pajak karena mereka takut terbukti melakukan tindakan kecurangan sehingga dapat terkena sanksi perpajakan yang berupa denda. Semakin tingginya kecurangan yang terjadi diperpajakan membuat kenerja penerimaan pajak tidak optimal. Maka hipotesisnya yaitu:

$\mathrm{H}_{2}$ :kecurangan teknologi berpengaruh negatif terhadap etika penggelapan pajak.

\section{Diskriminasi Dengan Etika Penggelapan Pajak}

McGee, et al (2008) diskriminasi berpengaruh terdahap etika penggelapan pajak. Apabila semakin tinggi tingkat diskriminasi dalam perpajakan maka perilaku penggelapan pajak cenderung dianggap tindakan yang etis. Maka hipotesisnya yaitu:

$\mathrm{H}_{3}$ : Diskriminasi berpengaruh positif terhadap etika penggelapan pajak

\section{Nilai sosial dengan Etika Penggelapan Pajak}

Masyarakat berasumsi dengan membayar pajak akan mengurangi pendapatan keuangan mereka. Sehingga lebih memilih penghindaran pajak secara ilegal. Sehingga dapat memengaruhi kepribadian individu satu dengan yang lain sebagai anggota masyarakat. Hal tersebut kita tidak sadari, dengan seiring tingkat sumber daya manusia dan pendapatan yang tumbuh dari waktu ke waktu, keuntungan pendapatan yang diharapkan dari melanggar hukum meningkat, sedangkan biaya marjinal yang diharapkan tetap konstan. Seperti yang terjadi, setelah tingkat sumber daya manusia tertentu, manfaat marjinal yang diharapkan melebihi biaya marjinal dan biaya moral tidak relevan.

$\mathrm{H}_{4}$ : nilai sosial berpengaruh positif terhadap etika penggelapan pajak

\section{Metode Penelitian Desain Penelitian}

Jenis investigasi dalam penelitian ini adalah causal relationship, menjelaskan hubungan antara suatu kejadian (sebab) dan kejadian kedua (akibat atau dampak), yang mana kejadian kedua merupakan konsekuensi dari suatu kejadian pertama. Tingkat intervensi dalam penelitian ini adalah rendah. Penelitian ini merupakan penilitian studi lapangan. Data yang dikumpulkan yang berupa kuesioner kepada setiap responden dengan unit analisisnya yaitu individual. Horizon waktu yang digunakan dalam penelitian ini adalah Cross Sectional.

\section{Populasi dan Sampel Penelitian}

Populasi dalam penelitian ini adalah wajib pajak yang berjumlah 239.899 orang yang terdaftar di Kantor Pelayanan Pajak kota Banda Aceh sampai dengan tahun 2018.

Sampel dalam penelitian ini adalah convenience sampling, yaitu kriteria/anggota sampel yang dipilih berdasarkan kemudahan memperoleh data yang di butuhkan. "Teknik penentuan sampel dengan pertimbangan lokasi yang mudah dan terjangkau". Kriteria sampel yang dipilih yaitu wajib pajak yang terdaftar di Kantor Pelayanan Pajak Kota Banda Aceh. Teknik pengumpulan sampel menggunakan rumus slovin.

\section{Teknik Pengumpulan Data}

Dalam penelitian ini teknik pengumpulan data yang digunakan adalah Penelitian Pustaka (Library Research) dan Kuesioner.

\section{Operasional Variabel}

Variabel independen dalam penelitian ini adalah keadilan, kecurangan teknologi, diskriminasi dan nilai sosial. Variabel dependen dalam penelitian ini adalah etika penggelapan pajak.

\section{Metode Analisis dan Pengujian Hipotesis}

Metode analisis terdiri dari Uji Kualitas Data dan uji asumsi klasik. Uji Asumsi Klasik ini terdiri dari uji multikolinieritas, uji heterokedastisitas dan uji normalitas.

Pengujian Hipotesis dalam penelitian ini terdiri dari Uji Signifikan Simultan (Uji Statistik F), Uji 
Signifikan Parsial (Uji Statistik t), Koefisien Determinasi $\left(\mathrm{R}^{2}\right)$.

\section{Hasil Penelitian Dan Pembahasan Hasil Penelitian \\ Deskripsi Objek Penelitian}

Penelitian ini bertujuan untuk menguji pengaruh keadilan, kecurangan teknologi, diskiriminasi dan nilai sosial terhadap persepsi wajib pajak mengenai etika penggelapan pajak (Tax Evasion) di KPP Pratama Banda Aceh.

\section{Karakteristik Responden}

Berdasarkan hasil pengamatan diperoleh data karakteristik responden dari kantor pajak pratama sebagai berikut. Responden berjenis kelamin laki-laki sebanyak 67 orang $(44,7 \%)$ dan berjenis kelamin perempuan sebanyak 83 orang $(55,3 \%)$. Usia responden 20-30 tahun 40 orang (26,7\%), usia $31-40$ 44 orang $(29,3 \%)$, usia $40-50$ tahun 50 orang $(33,3 \%)$ dan usia $>50$ tahun 16 orang $(10,7 \%)$. Tingkat pendidikan responden yang berjenjang diploma 50 orang $(33,3 \%)$, magister 25 orang $(16,0 \%)$, sarjana 68 orang $(45,3 \%)$, doktor 4 orang $(2,7 \%)$, dan lainnya 4 orang $(2,7 \%)$.

\section{Hasil Uji Kualitas Data \\ Hasil Uji Validitas Data}

Berdasarkan hasil pengolahan data pada tabel 4.3 dapat disimpulkan bahwa pertanyaan dinyatakan valid karena mempunyai nilai korelasi diatas nilai kritis sebesar 0,159 , sehingga semua pertanyaan yang terkandung dalam kuesioner penelitian ini dinyatakan valid untuk dilanjutkan peneliti yang lebih mendalam, karena tidak ditemukan adanya variabel yang tidak konsisten.

\section{Hasil Uji Reliabilitas}

Nilai koefisien Alpha untuk masing-masing variabel berada di atas 0,60, sehingga dapat disimpulkan bahwa kuisioner yang dijadikan sebagai alat ukur dalam penelitian ini layak untuk digunakan dalam pengujian lanjutan.

\section{Hasil Uji Asumsi Klasik Uji Normalitas}

Dalam penelitian ini untuk mengetahui normalitas distribusi dapat dilakukan degan cara melihat nilai regresi residual yang terdistribusi normal maka terletak di sekitar garis horizontal (tidak berpencar jauh dari garis diagonal).

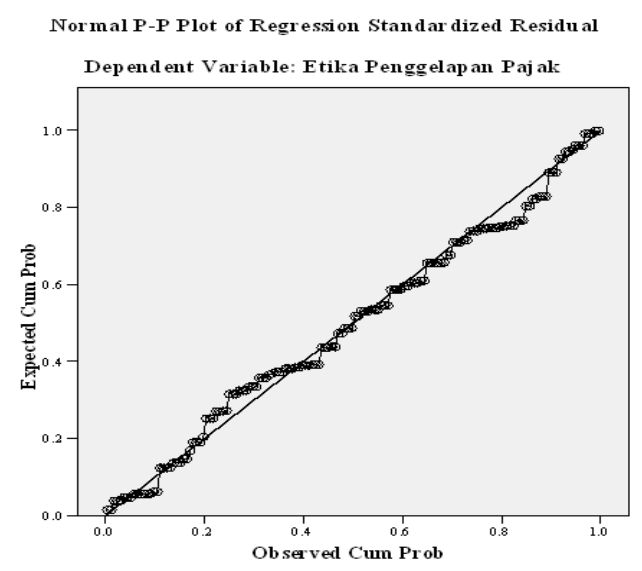

\section{Uji Multikolonieritas}

Bahwa nilai VIF masing-masing variabel independen yaitu keadilan pajak, kecurangan teknologi, diskriminasi dan nilai sosial berada dibawah 10. Nilai tolerance (TOL) yang diperoleh dari masingmasing variabel independen yaitu keadilan pajak, kecurangan teknologi, diskriminasi dan nilai sosial masih diatas 0,1. Hasil tersebut dapat diketahui bahwa dalam model regresi terbebas dari multikolonieritas antar variabel independen.

\section{Uji Heteroskedastisitas}

Scatterplot menunjukkan bahwa data menyebar dan tidak terdapat suatu pola yang jelas pada penyebaran data tersebut. Hal ini berarti tidak terjadi Heteroskedastisitas pada model persamaan regresi, sehingga model regresi layak digunakan untuk memprediksi etika penggelapan pajak berdasarkan variabel yang mempengaruhinya, yaitu keadilan pajak, kecurangan teknologi, diskriminasi dan nilai sosial.

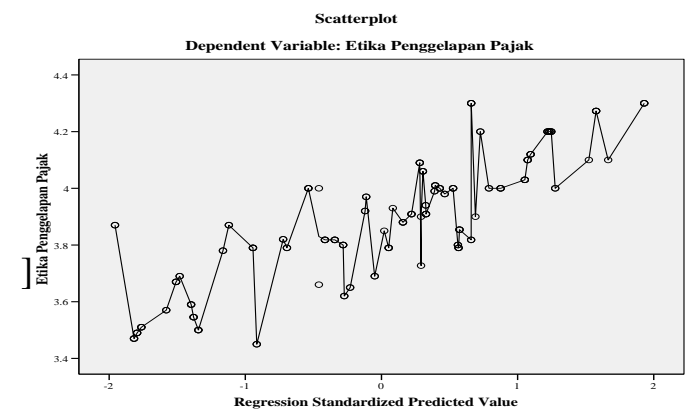




\section{Hasil Pengujian Hipotesis}

\section{Metode Regresi Linier Berganda}

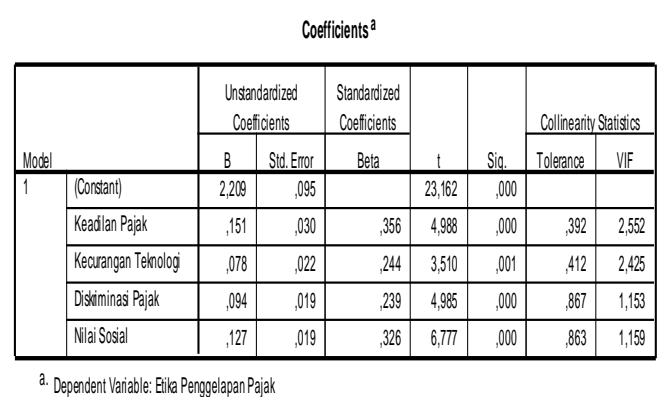

\section{Uji Signifikan Simultan (Uji Statistik F)}

Dari uji f dapat nilai f sebesar 88,954 dan signifikansi 0,000. Dengan demikian, hipotesis pertama yang menyatakan bahwa keadilan pajak (H1), kecurangan teknologi $(\mathrm{H} 2)$, diskriminasi (H3) dan nilai sosial (H4) bersama-sama berpengaruh terhadap etika penggelapan pajak dapat diterima.

\section{Uji Signifikan Parsial (Uji Statistik t)} berikut:

Hasil uji statistik $t$ menunjukkan sebagai

1) Variabel keadilan pajak (X1) memiliki nilai $t$ hitung 4,988 dan tingkat sigfikansi 0,000, lebih kecil dari 0,05 (5\%). Hal ini menunjukkan bahwa keadilan pajak berpengaruh secara signifikan terhadap etika penggelapan pajak. Dengan demikian, hipotesis ke dua $(\mathrm{H} 2)$ yang menyatakan bahwa keadilan pajak berpengaruh terhadap etika penggelapan pajak dapat diterima.

2) Variabel kecurangan teknologi (X2) memiliki nilai t hitung 3,510 dan tingkat sigfikansi 0,001, lebih kecil dari 0,05 (5\%). Hal ini menunjukkan bahwa kecurangan teknologi berpengaruh secara signifikan terhadap etika penggelapan pajak. Dengan demikian, hipotesis ke tiga (H3) yang menyatakan bahwa kecurangan teknologi berpengaruh terhadap etika penggelapan pajak dapat diterima.

3) Variabel diskriminasi (X3) memiliki nilai t hitung 4,985 dan tingkat sigfikansi 0,000 , lebih kecil dari 0,05 (5\%). Hal ini menunjukkan bahwa diskriminasi berpengaruh secara signifikan terhadap etika penggelapan pajak. Dengan demikian, hipotesis ke empat (H4) yang menyatakan bahwa diskriminasi berpengaruh terhadap etika penggelapan pajak dapat diterima.
4) Variabel nilai sosial (X4) memiliki nilai t hitung 6,777 dan tingkat sigfikansi 0,000, lebih kecil dari $0,05(5 \%)$. Hal ini menunjukkan bahwa nilai sosial berpengaruh secara signifikan terhadap etika penggelapan pajak. Dengan demikian, hipotesis ke lima (H5) yang menyatakan bahwa nilai sosial berpengaruh terhadap etika penggelapan pajak dapat diterima.

\section{Koefisien Determinasi $\left(\mathbf{R}^{2}\right)$}

Dari hasil penelitian didapat nilai $\mathrm{R}$ square diperoleh sebesar 0,710 atau sebesar 71,0\%. Dengan demikian dapat dikatakan bahwa $71,0 \%$ variasi etika penggelapan pajak dapat dijelaskan oleh ke empat variabel independen dalam penelitian ini, yaitu keadilan pajak, kecurangan teknologi, diskriminasi dan nilai sosial, sedangkan sisanya sebesar 29,0\% dijelaskan oleh variabel lain yang tidak di masukkan kedalam peneltian ini.

\section{Pembahasan}

Pengaruh Keadilan, Kecurangan Teknologi, Diskriminasi dan Nilai Sosial terhadap Persepsi Wajib Pajak Mengenai Etika Penggelapan Pajak

Berdasarkan hasil uji statistik secara simultan, menunjukkan bahwa tingkat signifikansi variabel keadilan pajak,kecurangan teknologi, diskriminasi dan nilai sosial berpengaruh bersama-sama terhadap etika penggelapan pajak dengan nilai signifikan 88,954

\section{Pengaruh Keadilan terhadap Persepsi Wajib Pajak mengenai Etika Penggelapan Pajak (Tax Evasion)}

Berdasarkan hasil uji statistik secara parsial keadilan pajak, menunjukkan bahwa tingkat signifikansi variabel keadilan pajak sebesar 0,000 lebih kecil 0,05, sehingga berpengaruh terhadap etika penggelapan pajak.

\section{Pengaruh Kecurangan Teknologi terhadap Persepsi Wajib Pajak mengenai Etika Penggelapan Pajak (Tax Evasion)}

Berdasarkan hasil uji statistik secara parsial kecurangan teknologi, menunjukkan bahwa tingkat signifikansi variabel kecurangan teknologi sebesar 0,001 lebih kecil 0,05, sehingga berpengaruh terhadap etika penggelapan pajak. 
Pengaruh Diskriminasi terhadap Persepsi Wajib Pajak mengenai Etika Penggelapan Pajak (Tax Evasion)

Berdasarkan hasil uji statistik secara parsial diskriminasi, menunjukkan bahwa tingkat signifikansi variabel diskriminasi sebesar 0,000 lebih kecil 0,05, sehingga berpengaruh terhadap etika penggelapan pajak.

\section{Pengaruh Nilai Sosial terhadap Persepsi Wajib Pajak mengenai Etika Penggelapan Pajak (Tax Evasion)}

Berdasarkan hasil uji statistik secara parsial nilai sosial, menunjukkan bahwa tingkat signifikansi variabel nilai sosial sebesar 0,000 lebih kecil 0,05, sehingga berpengaruh terhadap etika penggelapan pajak.

\section{Kesimpulan, Keterbatasan dan Saran}

Berdasarkan pembahasan hasil penelitian yang telah dikemukakan sebelumnya, dapat disimpulkan bahwa:

1) Hasil penelitian menunjukkan bahwa keadilan berpengaruh positif terhadap etika penggelapan pajak.

2) Kecurangan teknologi berpengaruh positif terhadap etika penggelapan pajak.

3) Diskriminasi berpengaruh positif terhadap etika penggelapan pajak.

4) Nilai sosial berpengaruh positif terhadap etika penggelapan pajak.

5) Hasil penelitian secara simultan menunjukkan bahwa variabel keadilan, kecurangan teknologi, diskriminasi dan nilai sosial berpengaruh bersamasama terhadap etika penggelapan pajak.

Penelitian ini mempunyai beberapa kelemahan yang membatasi kesempurnaannya. Oleh sebab itu, keterbatasan ini perlu diperhatikan dalam penelitian selanjutnya. Adapun keterbatasan sebagai berikut :

1) Variabel yang mempengaruhi keadilan, kecurangan teknologi, diskriminasi dan nilai diduga masih banyak variabel lain yang berpengaruh terhadap etika penggelapan pajak itu sendiri.

2) Penelitian ini hanya dilakukan pada satu lokasi kabupaten/kota, sehingga tidak dapat digeneralisir untuk wilayah kabupaten/kota lainnya, hal ini dikarenakan untuk menghemat waktu dan biaya yang dikeluarkan peneliti selama penelitian.

3) Data dianalisis berdasarkan instrument, yaitu kuesioner, sehingga kesimpulan yang diambil didasarkan pada data yang dikumpulkan kuesioner. Hal ini akan menimbulkan masalah jika jawaban responden berbeda dengan keadaan sesungguhnya. Keadaan seperti ini merupakan hal yang tidak dapat dikendalikan karena diluar kemampuan peneliti.

Berdasarkan penelitian yang telah dilaksanakan, maka diajukan saran-saran sebagai berikut:

1) Penelitian pada bidang yang sama sebaiknya dapat memperluas ruang lingkup penelitian, misalnya pengambilan sampel bisa dilakukan di lebih dari satu KPP sehingga diharapkan dapat meningkatkan keakuratan hasil penelitian.

2) Tidak hanya menggunakan kuisioner tapi juga melakukan wawancara secara langsung untuk mendapatkan informasi data penelitian dengan para wajib pajak agar mendapatkan data yang lebih akurat.

3) Menambah jumlah responden dan wilayah penelitian sehingga menambah sebuah penelitian yang lebih baik.

4) Menambahkan jumlah variabel independen yang dapat mempengaruhi penggelapan pajak, seperti ketepatan pengalokasian, pelayanan aparat pajak dan budaya yang berbeda.

5) KPP Pratama Banda aceh diharapkan untuk selalu mengevaluasi sistem kenerja aparat perpajakan dengan tujuan meningkatkan pelayanan dan mencegah terjadinya penggelapan pajak yang dilakukan oleh aparat perpajakan itu sendiri.

6) Diharapkan perlu adanya sosialisasi sedari dini tentang pentingnya sikap Wajib Pajak untuk taat dan patuh dalam melakukan kewajiban perpajakannya. Disamping itu juga perlu disosialisasikan secara lebih luas manfaat dari uang pajak yang telah disetorkan ke kas negara. Diharapkan dengan semakin tinggi kesadaran masyarakat membayar pajak, maka kecenderungan untuk melakukan pelanggaran dan tindakan tax evasion semakin rendah. 


\section{Daftar Pustaka}

Ayu, Stephana Dyah. 2009. Persepsi Wajib Pajak: Dampak Pertentangan Diametral pada Tax Evasion Wajib Pajak Dalam Aspek Kemungkinan Terjadinya Kecurangan, Keadilan, Ketetapan Pengalokasian, Teknologi Sistem Perpajakan, dan Kecenderungan Personal (Studi Wajib Pajak Orang Pribadi). Jurnal. Semarang : UNIKA.

Abrahams, N. B. \& Kristanto, A. B. 2016. Persepsi Calon Wajib Pajak dan Wajib Pajak terhadap Etika atas penggelapan pajak di Salatiga. Berkala Akuntansi dan Keuangan Indonesia, 1(1). Universitas Kristen Satya Wacana, Salatiga.

Agoes, Sukrisno \& Ardana, I Cenik. 2014. Etika Bisnis dan Profesi: Tantangan Membangun Manusia Seutuhnya. Jakarta: Selemba Empat.

Fikriningrum, Winda Kurnia. 2012. "Analisis FaktorFaktor Yang Mempengaruhi Wajib Pajak Orang Pribadi Dalam Memenuhi Kewajiban Membayar Pajak (Studi Kasus KPP Semarang Candisari)". Skripsi Fakultas Ekonomi dan Bisnis Universitas Diponegorwo. Semarang.

Hasibuan, R. P. S. 2014. Faktor-faktor yang mempengaruhi Persepsi Wajib Pajak mengenai Etika atas penggelapan pajak (Tax Evasion) (Studi Empiris di KPP Pratama MedanPolonia). Skripsi. Universitas Sumatera Utara, Medan.

Kimball, Y., 2003. Income distribution and equilibrium multiplicity in a stigma based model of tax evasion. J. Public Econ. 87, 1591-1616.

Kurniawati, Meiliana., \& Toly, A. A. 2014. Analisis Keadilan Pajak, Biaya Kepatuhan, dan Tarif Pajak terhadap Persepsi Wajib Pajak mengenai Penggelapan Pajak di Surabaya Barat. Tax \& Accounting Review, 4(2). Universitas Kristen Petra, Surabaya.

Lubis, A. I. 2010. Akuntansi Keperilakuan (2 ed.). Jakarta: Salemba Empat.

Mardiasmo. (2016). "Perpajakan Edisi Revisi 2016". Yogyakarta, Penerbit Andi.

McGee, R.W., Simon dan Annie. (2008). "A comparative Study on Perceived Ethics of Tax Evasion: Hong Kong Vs the United Stated", Journal of Business Ethics 2008, pp. 147-158.

Mukharoroh, A. H. 2014. Analisis Faktor-faktor yang mempengaruhi Persepsi Wajib Pajak mengenai penggelapan pajak (Studi Empiris pada Wajib Pajak Pribadi di Kota Semarang). Skripsi. Universitas Diponegoro, Semarang.

Nugroho, Rahman Adi. 2012. "Faktor-Faktor Yang Mempengaruhi Kemauan Untuk Membayar
Pajak Dengan Kesadaran Membayar Pajak Sebagai Variabel Intervening (Studi Kasus Wajib Pajak Orang Pribadi Yang Melakukan Pekerjaan Bebas Yang Terdaftar di KPP Pratama Semarang Tengah Satu)." Diponegoro Journal of Accounting. Vol. I. Semarang.

Nickerson, Inge. 2009. "Pleshko dan McGee. Presenting the Dimensionality of An Ethics Scale pertaining To Tax Evasion", Journal of Legal, Ethical and Regulatory Issues, Volume 12, Number 1.

Paramita, A.A Mirah Pradnya., \& Budiasih. 2016. Pengaruh Sistem Perpajakan, Keadilan, dan Teknologi Perpajakan pada Persepsi Wajib Pajak mengenai Penggelapan Pajak. E-Jurnal Akuntansi, 17(2). Universitas Udayana, Bali.

Siahaan, Marihot P. 2010. "Hukum Pajak Elementer". Yogyakarta, Penerbit Graha Ilmu.

Silaen, Charles. 2015. Pengaruh Sistem Perpajakan, Diskriminasi, Teknologi dan Informasi Perpajakan terhadap Persepsi Wajib Pajak Mengenai Etika atas penggelapan pajak (Tax Evasion). Jom FEKON, 2 (2). Universitas Riau, Pekan Baru.

Sekaran, Uma dan Roger Bougie. 2016. Research Methods for Business: A Skill-Building Approach. $6^{\text {th }}$ Ed. United Kingdom: Wiley.

Suminarsi, Wahyu dan Supriyadi. 2012. Pengaruh Keadilan, sistem Perpajakan

dan Diskriminasi terhadap Persepsi Wajib Pajak mengenai Etika Penggelapan Pajak (Tax Evasion). Jurnal Simposium Nasional Akuntansi XV No.672PAN-SNA15VII2012, Universitas Gajah Mada. Yogyakarta.

Suryani, Trisni dan Tarsis Tarmudji. 2012. "Pajak di Indonesia". Yogyakarta: Graha Ilmu.

Waluyo. 2010. "Perpajakan Indonesia". Jakarta. Salemba Empat.

Wikipedia.2016.

https/id.mwikipedia.org/wiki/Diskriminasi,diaks es2 Desember 2016. 